\title{
De avgående redaktörerna har ordet
}

SENASTE NUMRET AV Sociologisk Forskning är här, och med detta nummer säger vi från Lundaredaktionen tack för oss! Det har varit spännande år, framför allt för att det har gett oss en fin inblick i och insikt om hur mycket bra sociologisk forskning det görs runt om i landet. Det har också stärkt oss i övertygelsen om Sociologisk Forsknings viktiga plats i svensk sociologi. Det behövs ett forum som detta - i dag kanske mer än någonsin - där sociologi om och av forskare verksamma i Sverige kan presenteras, delas och debatteras.

En av de viktigare insatser vi som redaktion hoppas vi har kunnat bidra med för tidskriftens framtid är övergången till Open Journal Systems. Det som började med en suck över ohanterligt mejlande av manus och granskningar av en trött redaktör i Lundasociologernas lunchrum blev ett nytt, mer säkert, och betydligt mer lättarbetat manushanteringssystem, och en fin ny hemsida - tack vare Anders Hylmö. Stort tack till Anders, som inte bara genomförde själva överflyttningen och designade den nya hemsidan, utan dessutom pedagogiskt och tålmodigt guidade två relativt teknikovana redaktörer genom hela processen.

Som redaktörer har vi haft förmånen att omge oss med en fantastisk redaktion: Åsa Lundqvist, Diana Mulinari, Mikael Klintman och David Wästerfors har förstagranskat manus, rekommenderat lämpliga granskare, varit bollplank i svåra beslut, och kommit med fantastiska idéer om temanummer och nya textformat. Det har varit tryggt och tacksamt att vara redaktörer med en så kompetent redaktion i ryggen.

Ett extra varmt tack också till Annette Persson på RPform som har satt tidskriften under dessa år, och som hanterat våra ibland förvirrade (och nån gång till och med panikartade) produktionsprocesser med ett stort mått av professionalitet, flexibilitet och framförallt lugn och gott humör.

Vi vill också rikta ett varmt tack till alla de skribenter som sänt in sina alster under dessa år, och ett extra varmt tack till alla granskare som läst och kommenterat manus. Er arbetsinsats är osynlig men absolut avgörande för den vetenskapliga publikationens kvalitet. För att synliggöra er publicerar vi ett särskilt tack till er, i detta nummer.

I detta vårt sista nummer presenterar vi tre originalartiklar som alla presenterar och diskuterar empirisk ny forskning om aktuella ämnen. Sara Ekholm föreslår i artikeln "Oro för klimatförändringarnas konsekvenser. Klimatagerande och betydelsen av omsorg om kommande generationer" ett nytt analytiskt begrepp för att förstå dagens reaktioner på klimatkrisen, nämligen omsorgsoro. Utifrån en intervjustudie med föräldrar visar Ekholm hur begreppet kan fånga en mängd förhållningssätt som 
empati, omsorg, rättvisa, ansvar och oro gentemot människor i dag och kommande generationer. Hon presenterar också en typologi - de orosbejakande, de tillitsfulla, de kalkylerande och de trygghetssökande - som i sin tur leder till olika typer av klimatagerande.

I David Öborn Regin, Jonas Axelsson och Markus Arvidsons artikel "Tidslojalitet. En explorativ undersökning om hur tid och lojalitet flätas samman i fakultetsadministratörers arbetsstrategier" står det så kallade flexibla arbetslivet i fokus. Utifrån intervjuer med administratörer inom universitetsverksamhet visar författarna hur oreglerade arbetsramar nödvändiggör komplext navigerande mellan olika lojaliteter där allokering av tid blir centralt och kritiskt - något författarna benämner "tidslojalitet".

I "Membership in the digital era. Swedish trade unions' use of Internet and social media" gör Gabriella Scaramuzzino och Roberto Scaramuzzino en analys av fackföreningars användning av internet och sociala medier i kommunikationen med sina medlemmar. Med utgångspunkt i en kvalitativ studie av webbsidor, sociala mediekonton, samt intervjuer med representanter på två svenska fackföreningar visar författarna att organisationerna använder de digitala plattformarna för att stärka medlemskapet på redan givna premisser, snarare än att anpassa sig till de nya teknikerna.

Numret innehåller också fyra recensioner av nyutkomna verk: Jenny Alsarve recenserar Caitlyn Collins Making motherhood work (2019), Lars-Erik Berg läser Sverker Johanssons På spaning efter språkets ursprung (2019), Jayeon Lindellee gör en reflektion över Åke Sandbergs (red.) Arbete \& välfärd. Ledning, personal och organisationsmodeller i Sverige (2019) och i sin recension av Mötesboken. Tolkningar av arbetslivets sammanträden och rosévinsmingel (2019) av Patrik Hall, Vesa Leppänen och Malin Åkerström ställer sig Åsa Wettergren frågan vad ett möte egentligen är.

I Sociologförbundets text skriver Katarina Jacobsson om vad hon trodde hon skulle skriva om Sociologidagarna 2020 - innan covid-19 gjorde det omöjligt för sociologsverige att träffas. Hon tackar också för sig som ordförande för förbundet och presenterar den nya styrelsen, samt de som tilldelats pris för bästa avhandling 2018-2019 samt Torgny T. Segerstedts pris för bästa artikel i Sociologisk Forskning 2018 respektive 2019.

Så vill vi - som alltid - uppmana er att sända oss era manus, uppslag till recensioner och idéer för temanummer. Sociologisk Forskning publicerar bidrag på svenska och övriga skandinaviska språk samt engelska. Sociologisk Forskning tillämpar anonymiserad kollegial granskning (double blind peer review) och tidskriften indexeras i ett stort antal internationella databaser, publiceras med omedelbar öppen tillgång (open access) och finns tillgänglig genom JSTOR (se tidskriftens hemsida för vidare detaljer). Dessutom är den numera enkelt tillgänglig genom vår webbplattform, www.sociologiskforskning.se.

Slutligen - det är med varm hand och stor förväntan vi nu lämnar över till Södertörnredaktionen, med Magnus Wennerhag och Lena Sohl i spetsen. Vi är övertygade om att Sociologisk Forskning har spännande år framför sig med er vid rodret.

De avgående redaktörerna, Christofer Edling och Sara Eldén 